\title{
PROBLEM OSOBY W ŚWIETLE NEURONAUK. CZY OSOBA TO JEDYNIE UŻYTECZNA METAFORA?
}

\section{THE PERSON IN LIGHT OF NEUROSCIENCE: IS A PERSON ONLY A USEFUL METAPHOR?}

Starting from John Paul Il's critique of Cartesianism, this article shows the influence of the latter on the emergence of empirical-positivist (Gerhard Roth) and eliminational (Daniel C. Dennett) theories of the person that consider man merely a useful metaphor. The philosopher Peter F. Strawson and the neurologist Roger W. Sperry, who came up with the metaphysical and emergentist theories of the person, respectively, support the idea that the person is not merely illusory and metaphorical. An exclusively metaphorical understanding of the person also contradicts current research on neuroplasticity, as both studies on people with obsessive-compulsive disorder and the treatment of patients after the stroke demonstrate.

Key words: Cartesian dualism, reductionist theory of the person, eliminational theory of the person, metaphysical theory of the person, emergentist theory of the person, neuroscienctific theory of the human person, neuroplasticity, neuroscience.

\section{Wrowadzenie}

Problematyka osoby stanowi dla Jana Pawła II „szczególnie dogodny teren, na którym dokonuje się spotkanie z bytem, a tym samym z refleksją 
metafizyczną”. W tym spotkaniu metafizyka odgrywa „szczególnie ważną rolę w poszukiwaniach teologicznych"2. Interfilozoficzne analizy pojęcia osoby znajdujemy zwłaszcza w jego pracy Osoba i czyn. Za Karolem Wojtyłą można je traktować jako swoistą rozbudowę arystotelesowsko-tomistycznej interpretacji teorii actus humanus, o której przyszły Papież pisze, że: „Interpretacja ta jest na swój sposób doskonała” i dodaje, iż zamierza ją „w dalszym ciągu rozwijać i naświetlać w szeregu aspektów"3.

W niniejszym opracowaniu zamierzam poddać analizie filozoficzną tematykę osoby, omawianą przez Jana Pawła II od strony szeroko rozumianego „kartezjanizmu". Przejawem tego ostatniego jest, zdaniem Papieża, podkreślanie subiektywności osoby, metoda separacji i redukcji oraz mechanicyzm jako swoisty projekt zmierzający do zrozumienia, a w konsekwencji do opanowania przyrody. Krytykując „kartezjanizm”, Jan Paweł II uważa, że uprawianie filozofii postawił on na głowie, podporządkowując Tomaszowe bycie (esse) poznaniu (cogito). W konsekwencji rozwijające się w duchu kartezjańskim (tzn. odrzucające badanie bycia) filozofia nowożytna i współczesna skupiły się na ludzkim poznaniu.

Pragnę ze swojej strony dodać, że tak rozumiany „kartezjanizm” leży u podstaw współczesnego, interdyscyplinarnie rozumianego problemu ciało-umysł (body-mind problem), w ramach którego pojawiają się eliminatywistyczne wypowiedzi o iluzoryczności osoby jako takiej czy o metaforycznym rozumieniu pojęcia osoby.

Najpierw naszkicuję zasadnicze punkty tworzące trzon filozofii Kartezjusza, pokazując na ile ich stopniowa ewolucja doprowadziła do współczesnego, eliminatywistyczno-redukcjonistycznego rozumienia nauki, co zaowocowało w konsekwencji tezą o iluzoryczności osoby, wyrażającą się w metaforycznym sposobie mówienia o niej.

Jako przykład eliminatywistycznej argumentacji przytoczę głównie publikacje filozofa Daniela C. Dennetta, wspominające prace neuronaukowców Wolfa Joachima Singera oraz Gerharda Rotha. Wskażę zarazem na punkty wspólne tych prac z kartezjanizmem. W swojej krytyce ujęć eliminatywistycznych wychodzę od Petera F. Strawsona pojęcia osoby. Używając współczesnej terminologii, na nowo interpretuje on Arystotelesowskie pojęcie indywidualnej substancji. Następnie, powołując się na badania neurologa Rogera Sperry'ego, opowiadam się za emergencyjną koncepcją osoby, przeczącą tezie o jej jedynie

Jan Paweł II, Encyklika Fides et ratio, Poznań 1998, nr 83.

Ibidem.

K. Wojtyła, Osoba i czyn, Kraków 1969, s. 30-31. Por. idem, Pamięć i tożsamość, Kraków 2005, s. 47-50. 
iluzorycznym istnieniu. Wskazuję przy tym na związki emergencyjnej teorii osoby z jej ujęciami proponowanymi zarówno przez Strawsona, jak i przez filozofię arystotelesowsko-tomistyczną, do której nawiązuje Jan Paweł II. Pozostając na polu neuronauk (tj. nauk interdyscyplinarnych, korzystających $z$ anatomicznych i funkcjonalnych badań systemu nerwowego oraz łączących je $z$ badaniami psychospołecznymi i medycznymi), pokazuję, że metaforycznemu rozumieniu osoby przeczą chociażby badania nad neuroplastycznością mózgu.

\section{Kartezjanizm}

W Przekroczyć próg nadziei Jan Paweł II stawia tezę, że od wielu lat w filozofii dominuje sposób jej uprawiania, który jest czysto racjonalistyczny,

[...] właściwy dla filozofii nowożytnej. Dzieje tej filozofii rozpoczynają się wraz

z Kartezjuszem, który myślenie w pewnym sensie oderwał od całej egzystencji,

a związal je z samym rozumem: Cogito ergo sum ${ }^{4}$.

Terminem „racjonalizm” Jan Paweł II obejmuje dwa z wymienionych przeze mnie kartezjańskich tematów: zwrot ku subiektywności i metodę redukcyjną. W encyklice Fides et ratio przewijają się trzy kartezjańskie tematy: subiektywność osoby, metoda separacji i redukcji oraz mechanicyzm jako swoisty projekt zrozumienia, opisania i opanowania przyrody.

Według Papieża, zwrot ku subiektywności niesie ze sobą zarówno bunt przeciwko naszemu statusowi bytów stworzonych, jak i próbę przezwyciężenia dystansu między Bogiem a człowiekiem. Zwrot ten spowodował, że teologiczna rzeczywistość historii Zbawienia uległa zapomnieniu i zaciemnieniu, a Kartezjusz stworzył „klimat, w którym w nowożytnej epoce takie odejście [od chrześcijaństwa - przyp. J.B.] mogło się urzeczywistnić”, prowadząc tym samym do przesunięcia refleksji filozoficznej ku antropocentryzmowi, co w konsekwencji spowodowało redukcję tej refleksji jedynie do kwestii istnienia „Boga pozaświatowego”.

Subiektywność i redukcja stały się mottem dla nowożytnego i współczesnego racjonalizmu. Kartezjusz absolutyzuje autonomiczne myślenie, stawiając je w opozycji do rozwiniętej przez św. Tomasza filozofii istnienia oraz w opozycji do jego rozumienia Boga jako Ipsum esse subsistens. Kartezjusz, „ojciec racjonalizmu”, ustawił nas w ten sposób „na progu nowoczesnego immanentyzmu i subiektywizmu”. Kartezjusza Rozprawa o metodzie stanowi, według Jana

4 Jan Paweł II, Przekroczyć próg nadziei, Lublin 1994, s. 47. Por. idem, Pamięć i tożsamość, s. 17.

$5 \quad$ Idem, Przekroczyć próg nadziei, nr 56.

$6 \quad$ Ibidem, nr 55. Por. idem, Encyklika Fides et ratio, nr 81, por. ibidem, nr 5. 
Pawła II, jedno z głównych źródeł współczesnego subiektywizmu i racjonalizmu. Papież podkreśla, że właśnie to dzieło przyczyniło się stworzenia intelektualnego klimatu sprzyjającego rozdzieleniu wiary i rozumu.

Odrzucając filozofię arystotelesowsko-tomistyczną, Kartezjusz dąży do stworzenia fundamentów pod nową filozofię, w której,

znając siłę i działanie ognia, wody, powietrza, gwiazd, nieba i wszystkich innych ciał, które nas otaczają, równie dokładnie, jak znamy rozmaite rękodzieła naszych rzemieślników, będziemy mogli użyć ich w ten sam sposób do wszystkich celów, do których się nadają, i dzięki temu stać się panami i posiadaczami natury ${ }^{7}$.

W opanowaniu przyrody pomoże nie tradycyjna metafizyka, lecz dyscypliny naukowe tworzone na fundamencie matematyki. Tak rozumiana filozofia prowadzi, według Jana Pawła II, do tworzenia zsekularyzowanego, scjentystycznego społeczeństwa, które będzie bronić

humanizmu całkowicie oderwanego od Boga i całkowicie skoncentrowanego na kulcie działania oraz produkcji, wypaczonego przesytem konsumpcji i przyjemności, nie troszczącego się o niebezpieczeństwo „utraty własnej duszy”.

Proponowana przez Kartezjusza „nowa metoda” prowadzenia badań zaczyna od uniwersalnego wątpienia w to, co nie jest jasne i wyraźne, od usunięcia na bok tradycyjnych ujęć obecnych we wszystkich obszarach wiedzy, w celu umożliwienia użytecznego i pewnego poznania naukowego.

Występująca w nauce pewność ma być zagwarantowana dzięki użyciu prostych formuł, takich jak zasady mechaniki, zaś nabywanie poznania ma pozostawać zgodne z metodą analityczną, wedle której problem należy podzielić na drobne części, a następnie stworzyć z nich wyższy poziom złożoności.

Kartezjanizm może zostać przezwyciężony, zdaniem Jana Pawła II, poprzez powrót do tradycji greckiego i średniowiecznego myślenia. Potrzeba do tego klimatu, w którym ośmielimy się na nowo pytać o prawdę bycia.

Trzecia konsekwencja filozofii Kartezjusza - radykalny dualizm substancjalny - wynika z pojęciowo-ontologicznego rozdzielenia świadomości osoby od jej ciała. Z jednej strony, pozwala on na badanie ciała tymi samymi technicznymi metodami, jakimi się bada wszystkie inne przedmioty i zjawiska w przyrodzie, $z$ drugiej strony, zaciemnia chociażby znaczenie sumienia (jako aktu rozumowego poznania dokonywanego przez osobę, która w określonej sytuacji ma zastosować wiedzę uniwersalną) oraz zaciemnia znaczenie cnót

\footnotetext{
$7 \quad$ Kartezjusz, Rozprawa o metodzie, tłum. T. Boy-Żeleński, Warszawa 1934, s. 131. 
jako przyzwyczajeń, nawyków do osobistych wyborów i do ćwiczenia się osoby w samoopanowaniu?.

\section{Daniel C. Dennett - eliminatywizm jako forma współczesnego kartezjanizmu}

Według kartezjańskiego dualizmu, jakiekolwiek zjawiska spotykane w świecie podpadają pod jedną z dwóch kategorii: mentalną albo fizyczną. Ludzkie res cogitans jest substancją nieprzestrzenną, wszystko inne jest res extensa - substancją rozciągłą.

Z jednej strony, tak rozdzielone obydwie kategorie są przyczynowo zamknięte, $z$ drugiej, codziennie obserwujemy, że to, co fizyczne, oddziałuje na to, co mentalne (np. zażywanie narkotyków wywołuje błogie stany) i odwrotnie (często samo mentalne wyobrażenie sobie jakiejś sceny powoduje chociażby szybsze bicie serca). Tym samym otrzymujemy trylemat trzech założeń trudnych ze sobą do pogodzenia ${ }^{10}$ :

(1) stany mentalne nie są stanami fizycznymi;

(2) stany mentalne oddziałują przyczynowo na stany fizyczne;

(3) obszar tego, co fizyczne, jest przyczynowo zamknięty, przy czym przyczyna jest rozumiana w sensie arystotelesowskiej przyczyny sprawczej.

Zdanie (3) stoi w konflikcie z (1) oraz (2). Jeśli obszar zjawisk fizycznych jest przyczynowo zamknięty (3), to stany mentalne, jak założono w (2), nie mogą oddziaływać, gdyż w (1) przyjęto, że są one „nie-fizyczne”.

W tle założenia (3) leży paradygmatyczna teza metodologicznego, kartezjańskiego fizykalizmu, wspierająca zarazem uniwersalność jego dualizmu: przezwyciężyć zarówno arystotelesowską dynamikę (tzn. jego ujęcie ruchu jako przejścia do stanu możliwego), jak i jego rozróżnienie na dynamikę w świecie pod-i nadksiężycowym.

Przeciwko założeniu (3), że zjawiska fizyczne mogą mieć jedynie przyczyny fizyczne, przemawia teza o tzw. przyczynowości mentalnej, „przyczynowości skierowanej ku dołowi”, (downward causation). Przyjęcie przyczynowości mentalnej może prowadzić do:

(i) tezy materialistycznej przyjmującej, że stany mentalne - zakładając, iż wpływają przyczynowo na stany fizyczne - muszą także mieć naturę fizyczną;

(ii) tez nieredukcjonistycznych (np. w teoriach emergencji), w których przyczynowość skierowaną ku dołowi rozumie się analogicznie do arystotelesowskiej przyczyny formalnej, a nie do przyczyny sprawczej.

$9 \quad$ Por. idem, Encyklika Fides et ratio, nr 98.

10 Trylemat ten omawiam bliżej w: J. Bremer, Wprowadzenie do filozofii umystu, Kraków 2010, s. 30-32. 
Problem z przyczynowością skierowaną ku dołowi polega na tym, że brak nam jednoznacznych praw psychofizycznych, tzn. praw lączących stany mentalne ze stanami fizycznymi. Rozumienie przyczynowości skierowanej ku dołowi prowadzi - analogicznie do arystotelesowskiej przyczyny formalnej - do rewizji założenia (3).

Daniel C. Dennett (którego, używając języka Jana Pawła II, możemy nazwać przedstawicielem „umysłowości pozytywistycznej” ${ }^{11}$ ) uważa, że jeśli istniałoby coś mentalnego (duchowego), to musiałoby to coś być czymś wyłącznie przyczynowo zamkniętym, czymś mentalnym-samym-w-sobie. Czegoś takiego nie ma, a „świadomy duch" jest jedynie „przyzwyczajeniem naszego myślenia”" W książce Consciousness Explained (1991) Dennett stara się owo stare przyzwyczajenie zdemaskować jako iluzjonistyczne urojenie, które nie da się pomyśleć w inny aniżeli kartezjański sposób.

Tym samym Dennett, podobnie jak filozofowie Gilbert Ryle i Willard V.O. Quine $^{13}$, okazuje się być kryptokartezjanistą wtedy, gdy jest przekonany, że to, co mentalne, może istnieć tylko, jeśli jest odróżnialne od tego, co fizyczne i może być od niego oddzielone. Ponieważ jednak to, co mentalne, nie może się pojawić bez tego, co fizyczne, więc - według nowych kartezjanistów - to, co mentalne, nie istnieje. $Z$ drugiej strony opowiada się on za monistycznym materializmem, co także prowadzi go do eliminacji tego, co mentalne.

Ostatecznie eliminatywizm zostaje przez Dennetta przyjęty na podstawie monistycznej ontologii. Dla monisty-materialisty wszystko da się utożsamić z tym, co fizyczne, czyli z naukowo obserwowalnymi fizycznymi ciałami. Dennettowi, jako przedstawicielowi eliminatywizmu, stanowisko takie nie wystarcza, ponieważ - mimo innego słownictwa - odnosi się ono nadal do tego, co mentalne. Wyeliminować należy zatem nie tylko wyrażenia mentalne, lecz także ogólne odnoszenie się (referencję) do tego, co mentalne. Dopiero wówczas znikną problemy, jakie potocznie wiążą się z tym, co mentalne.

Wniosek stąd jest jeden: jeśli w ogóle istnieje coś mentalnego (duchowego), to tylko jako coś epifenomenalnego, jako zjawisko towarzyszące, które jednak przyczynowo - czy to jako przyczyna sprawcza, czy jako przyczyna skierowana ku dołowi - nic nie „wywołuje”, gdyz mentalne, oddzielone od tego, co fizyczne, nie wpływa przyczynowo na coś fizycznego. Zjawiska mentalne są więc nierzeczywiste. Można metaforycznie mówić o „czymś duchowym”, eliminując

$11 \quad$ Jan Paweł II, Przekroczyć próg nadziei, s. 44.

12 D.C. Dennett, Consciousness Explained, Boston (MA) 1991, s. 37.

13 Eliminatywizm Ryle’a i Quine’a omawiam bliżej w: J. Bremer, Wprowadzenie do filozofii umystu, s. 89-97, 111-120. 
jednak to od strony ontologicznej, co prowadzi do metaforycznego używania słownictwa w odniesieniu do tego, co ma charakter mentalny.

Operująca pojęciem osobowej jaźni psychologia potoczna mówi ostatecznie o urojeniu:

Nie istnieje pojedynczy, jednoznacznie określony, „strumień świadomości”, ponieważ [...] nie istnieje Teatr Kartezjański, gdzie „wszystko schodzi się razem”, aby móc zostać przeczytanym przez jakiegoś Centralnego Dawcę Znaczenia. Zamiast tego istnieje wiele kanałów, w których specjalne obwody próbują, w paralelnych kotłowaninach, realizować swoje rozmaite zadania, tworząc stopniowo Wiele Szkiców ${ }^{14}$.

Potocznie rozumiana osoba to postulowany podmiot, swego rodzaju fikcyjne „do wszystkich, których to może dotyczyć”, któremu faktycznie, my stojący z boku, poprawnie przypisalibyśmy przekonanie, że ów podmiot czegoś doznał, coś przeżył ${ }^{15}$.

Dennett rezygnuje z poszukiwań jakiejś realnej - cechującej się jednością i tożsamością - jaźni i mówi o niej jako o postulowanej, teoretycznej fikcji ${ }^{16}$. Ta fikcyjna jaźń każdego z nas jest podmiotem wszystkich, pochodzących od każdego z nas i tworzących nas, opowiadań.

Z jednej strony, Dennett jest kognitywistą-eliminatywistą, z drugiej, jest on - gdy chodzi o świadome przeżycia - neurofizjologicznym realistą ${ }^{17}$. Fikcyjne jaźnie i przeżycia każdego $z$ nas są konstruowane na podstawie dostępnych nam sądów. Kto jednak wypowiada owe sądy, które konstruują jaźn i przeżyciowy świat? Dennett odpowiada: każdy z nas, ale jedynie jako podmiot czysto i wyłącznie fizykalny.

\section{Peter F. Strawson - opisowa metafizyka osoby}

Potocznie i często bezrefleksyjnie mówimy, że osoba posiada własności mentalne oraz fizyczne, że chodzi przy tym o tę samą, cechującą się jednością i tożsamością osobę X. Od takiego rozumienia osoby wychodzi Peter F. Strawson w swojej książce Indywidua. Próba metafizyki opisowej. Należy ona do opracowań z zakresu z metafizyki opisowej, tzn. opisującej struktury naszego myślenia, uznającej doraźność naszych teorii i rozwiązań oraz zamierzającej przedstawiać schematy pojęciowe $z$ należnym im zorientowaniem na rzeczywistość.

\footnotetext{
14 D.C. Dennett, Consciousness Explained, s. 253.

15 Ibidem, s. 128.

16 Ibidem, s. 227.

17 „Świadome przeżycia są realnymi zdarzeniami zachodzącymi w realnym czasie i w przestrzeni mózgu, i dlatego są one uchwytne czasowo i przestrzennie we właściwych dla tego rodzaju realnych zjawisk granicach precyzji”. D.C Dennett, M. Kinsbourne, Time and the Observer, "Behavioral and Brain Sciences" 1982, t. 15, nr 2, s. 235.
} 
Metafizykami opisowymi są, według Strawsona, Arystoteles i Kant, metafizykami rewidującymi - Kartezjusz i Leibniz. Metafizycy rewidujący poszukują nowych, lepszych opisów naszego myślenia i działania. Dzięki pracom Strawsona analizy metafizyczne powróciły do angloamerykańskiej filozofii osoby. Strawson pisze:

(SO) Przez pojęcie osoby rozumiem pojęcie pewnego typu bytu, takiego, że zarówno orzeczniki przypisujące stany świadomości, jak też orzeczniki przypisujące własności cielesne, sytuacje fizyczne itd. stosują się w równej mierze do pojedynczego indywiduum tego jednego typu ${ }^{18}$.

W pojęciu osoby (SO) Strawson łączy rozważania metafizyczne z filozofią języka. Starając się opisać aktualną strukturę osoby (indywiduum) za pomocą pojęć „tożsamość” i „jedność”, wychodzi poza granice pojęciowe oraz ontologiczne, nakreślone przez redukcjonistycznie i empirycznie zorientowanych filozofów i naukowców.

Dla Arystotelesa przykładem „pierwszej substancji”, pierwotnego obiektu, był pojedynczy człowiek, jak Sokrates, czy pojedyncze zwierzę, np. pewien koń. Z takich samych założeń wychodzi Strawson ${ }^{19}$, krytykując zarówno:

(i) kartezjańską koncepcję osoby, przypisującą świadomość substancji mentalnej całkowicie różnej, lecz jednak jakoś powiązanej z ciałem, oraz

(ii) „nowoczesną” teorię ,jaźni bez właściciela”, według której stany świadomości nie są, dokładnie mówiąc, przypisane w ogóle do niczego ${ }^{20}$.

Obydwie te koncepcje są, jego zdaniem, niespójne, stąd propozycja wyjścia od pojęcia osoby jako pojęcia pierwotnego (prymitywnego). Stany świadomości i stany fizyczne są przypisywane do jednego i tego samego indywiduum - do osoby (SO). Pojęcia umysłu i ciała zakładają pojęcie osoby (są z niego wyprowadzane).

Pojęcia osoby nie da się tym samym ani wyeliminować, ani zredukować do pojęcia ciała, czy umysłu, ani też nie da się go z tych pojęć złożyć. Uznanie pierwotności pojęcia osoby pozwala zobaczyć dlaczego zarówno stany świadomości, jak i stany fizyczne, są przypisane do czegoś, do tego samego indywiduum.

Spostrzeganie przez osobę siebie i swojego otoczenia zależy od jej ciała, które podpada pod szeroko rozumiane badania prowadzone metodami empirycznymi. Bez wątpienia, ciało posiada specjalny status dla osoby, ale mimo wszystko wydaje się, że związek między ciałem a podmiotem jest natury przypadkowej,

18 P. F. Strawson, Indywidua. Próba metafizyki opisowej, tłum. B. Chwedeńczuk, Warszawa 1980, s. 99.

19 Por. A.M. Martins (red.), Cause, Knowledge and Responsibility, Wien 2015, s. 115.

20 Strawsona ujęcie osoby analizuję dokładniej w: J. Bremer, Osoba-fikcja czy rzeczywistość? Tożsamość i jedność Ja w świetle badań neurologicznych, Kraków 2008, s. 56-76. 
a nie koniecznej (co Strawson potwierdza, odwołując się do różnego typu eksperymentów myślowych).

Zaliczany do filozofów „języka potocznego” Strawson zaznacza, że mówiąc o poziomie pierwszoosobowym należy dodać, iż mój stosunek do mojego ciała jest chociażby dlatego wart podkreślenia, gdyż licznych czasoprzestrzennych własności nie przypisuję ciału, lecz przypisuję je raczej sobie, mówiąc np. „ja marznę" (a nie „moje ciało marznie”).

Nie jest do końca jasne, co uzasadnia taki nasz sposób mówienia. Przyczynowy związek między osobą a ciałem nie dostarcza w każdym razie żadnego wyjaśnienia dlaczego mówiąc „,ja marznę” używamy zaimka „ja”. Gdy wskazując na moją pierś, powiem „oto ja”, to nie uznamy, że jestem moją piersią. Z żadną częścią mojego ciała, nawet z głową, nie jestem w ten sposób identyczny, że tworzy ona moje ja.

Zdaniem Strawsona, tezę o pierwotności pojęcia osoby (w stosunku do przypisywanych jej własności) można dostrzec przede wszystkim przy pytaniach typu: dlaczego w ogóle przypisujemy czemuś/komuś stany świadomości? Dlaczego przypisujemy je tej samej rzeczy, której przypisujemy własności cielesne? Odpowiadając Strawson zaznacza:

Warunkiem koniecznym przypisywania w ogóle stanów świadomości jest to, że mamy je przypisywać dokładnie tym samym rzeczom, którym przypisujemy pewne własności cielesne, pewną sytuację fizyczną itd. ${ }^{21}$.

Stanów świadomości nie można by w ogóle komuś przypisywać, jeśli nie byłyby one przypisywane osobom w sensie, jak je rozumie Strawson. W wypowiedziach o stanach świadomości, musi być możliwe przypisywanie ich w takim samym stopniu - sobie samemu i innym podmiotom, używając tych samych predykatów. Wyrażenia „ją boli ząb” i „mnie boli ząb” odnoszą się do tej samej własności.

\section{Neuronauki - Roger W. Sperry}

We współczesnej nauce spotyka się jednak częściej tendencje odwrotne do prezentowanych przez Strawsona, czyli tendencje redukcjonistyczno-eliminacyjne. Przykładem takiego podejścia jest zmarły w roku 2004 laureat Nagrody Nobla (1962), neurolog i biolog molekularny Francis Crick, bezgranicznie ufający w skuteczność czysto „naukowych” metod badania świadomego umysłu.

$21 \quad$ P. F. Strawson, Indywidua, s. 99. 
Zaznacza on, że „świadomość jest problemem naukowym”, a filozofia świadomej osoby jest jedynie nudną zabawą ${ }^{22}$.

Podobne stanowiska można znaleźć w pracach filozofujących neurologów Gerharda Rotha (wolna wola osoby jest iluzją) i Wolfa J. Singera (potoczne doświadczenie ,ja” jest jedynie konstruktem kulturowym) ${ }^{23}$.

Odmiennego zdania jest inny laureat Nagrody Nobla (1981), neurobiolog Roger W. Sperry, który przyznaje, że nauka stara się nam wykazać, że osoba i wolna wola są iluzją, a sens ludzkiego działania da się sprowadzić do funkcjonowania kompleksowych, biochemicznych systemów ${ }^{24}$.

Sperry odcina się od tego rodzaju stanowisk redukcyjno-fizykalistycznych oraz od stanowisk dualistycznych i zalicza siebie do interakcyjnych emergentystów. Zdarzeń mentalnych nie da się odseparować od mózgu, z którego emergują, do którego są nieredukowalne, ponadto zdarzenia mentalne są zdolne do przyczynowego oddziaływania na mózg (por. wspomniana przyczynowość skierowana ku dołowi).

Neurolog Colwyn Trevarthen (uczeń Sperry'ego) zaznacza, że jego mistrz poszukiwał nowej teorii świadomych zdarzeń mentalnych ${ }^{25}$, przyjmując, że emergentne, świadome zdarzenia mentalne mają wpływ na leżące u ich podstaw procesy neurologiczne (downward causation).

Materialistyczno-redukcjonistyczne i eliminatywistyczne teorie osoby, w ich różnych odmianach, mają problem z przedstawieniem najbardziej podstawowego faktu - posiadania przez nią samoświadomej jaźni. Sperry nigdy nie był usatysfakcjonowany materialistyczną tezą:

[...] że zupełne wyjaśnienie funkcji mózgu jest możliwe w czysto obiektywnych terminach, bez jakiegoś odniesienia do subiektywnych przeżyć, tzn. że w analizie naukowej możemy przekonująco i z korzyścią dla siebie zignorować subiektywne własności procesów mózgowych ${ }^{26}$.

Sperry nie odrzuca neurologicznych metod badania świadomości i nie zaleca powrotu do metod introspektywnych. Nie zakłada jednak, że wrażenia i inne

22 Por. F. Crick, Visual Perception: Rivalry and Consciousness, "Nature" 1996, nr 379, s. 485-486.

23 Tezy Rotha i Singera omawiam w: J. Bremer, Neuronaukowy i potoczny obraz osoby w kognitywistyce, Kraków 2017, s. 39-47.

24 Por. R. Sperry, Mind, Brain, and Humanist Values, [w:] New Views of the Nature of Man, J.R. Platt (red.), Chicago 1965, s. 73.

25 Por. C. Trevarthen, Editor's Preface, [w:] Brain Circuits and Functions of the Mind, red. C. Trevarthen, Cambridge 1990, s. xxxiii.

26 R. W. Sperry, Discussion, [w:] The Central Nervous System and Behavior, M. A. B. Brazier (red.), Princeton (NJ) 1959, s. 420. 
subiektywne przeżycia osoby nie posiadają żadnej funkcji, żadnej wartości operacyjnej, żadnego miejsca we współcześnie używanych modelach mózgu.

Z jednej strony, według Sperry'ego, epifenomenologiczna teza, że zjawiska subiektywne nie odgrywają przyczynowej roli w zdarzeniach neuronalnych, wydaje się zrozumiała i jasna. Z drugiej strony przyznajemy, że subiektywne zdawanie sobie sprawy w ogólności (np. ból per se) pojawia się w ewolucji systemu nerwowego, a świadomość może być zachowana, różnicowana i realnie używana, może też posiadać operacyjne znaczenie w łańcuchu przyczynowym.

Dlatego należy zapytać, czy jakiś neurofizjologiczny model osoby, uwzględniający jej uwarunkowane odpowiedzi, lecz nie uwzględniający jej nastawień subiektywnych, nie będzie obarczony swoistą luką w wyjaśnianiu.

Sperry stwierdza, że tezy redukcyjno-behawiorystyczne i eliminatywistyczne uznające, że neuronauki potrafią dostarczyć pełnego zrozumienia zdarzeń neuronalnych, dokonują zbyt dalekiej ekstrapolacji i pomijają potoczne rozumienie osoby. Subiektywne wrażenia osoby odgrywają bowiem zasadniczą rolę w funkcjonowaniu jej mózgu.

Dlatego, jego zdaniem, behawioryzm i teorie redukcjonistyczne muszą zostać zastąpione nową teorią, uwzględniającą pojęcie świadomości, przyjmującą założenia teorii emergencji. Swojej teorii umysłu Sperry nie utożsamia z dualizmem kartezjańskim. Umysł bez mózgu jest pozbawiony czegoś istotnego, chociażby pewnej formy przepływu energii (np. niedotlenienie mózgu odbija się na stanach świadomości). Sperry pisze:

Oddziaływania mentalne kierują i określają wewnętrznym ruchem impulsów, włącznie $z$ jego elektrochemicznymi i biofizycznymi aspektami [...]. W proponowanym tutaj modelu mózgu przyczynowe oddziaływania jakiejś idei, czy ideału, są tak rzeczywiste, jak te jakiejś cząstki, komórki czy impulsu nerwowego. Idee wywołują przyczynowo idee i pomagają ewoluować nowym ideom ${ }^{27}$.

Proponowany przez Sperry'ego mentalistyczny model świadomości, opierający się na teorii emergencji, doprowadził m.in. do tego, że w ciągu następnych dziesięciu lat zrelatywizowane zostało znaczenie materialistycznych teorii redukcjonistycznych i eliminatywistycznych, jako teorii dominujących w filozofii i psychologii umysłu.

Sperry rozumie świadomy umysł osoby jako całkowicie naturalny proces, emergujący z neuronalnej aktywności, różny od niej, ale równocześnie od niej nieoddzielny. Świadomość jest związana ze wspomnianą generalną zasadą zwaną „makrodeterminizmem”, w której mentalne, tzn. ewolucyjnie wyższe, bardziej rozwinięte własności przyrody oddziaływają i kontrolują swoje niższe komponenty. Jego rozumienie świadomości zakłada i integruje

27 R.W. Sperry, Mind, Brain and Humanist Values, s. 82. 
makrodeterminizm z mikrodeterminizmem, a przyczynowe oddziaływanie stanów mentalnych wymaga uwzględnienia we wszystkich naukach, nie tylko w psychologii czy w filozofii.

\section{Badania empiryczne - dwa przykłady}

W obydwu poniższych przykładach, ukazujących przyczynowe oddziaływanie świadomych procesów mentalnych na mózg osoby, odwoluję się do zjawiska neuroplastyczności mózgu.

Neuroplastyczność to cecha mózgu uzdalniająca go do adaptacji, zmienności, samonaprawy, uczenia się i zapamiętywania. Pozwala ona zarówno na powolne, ewolucyjne zmiany dokonujące się na przestrzeni wielu pokoleń, jak i na zmiany w krótszej perspektywie czasowej, np. dokonujące się każdego dnia. W naszych mózgach zachodzą funkcjonalne i strukturalne zmiany, w odpowiedni sposób dostosowując nasze reakcje do aktualnych wymagań.

1. Według profesora psychiatrii Jeffreya M. Schwartza, konwencjonalna nauka długo obstawała przy stanowisku, że świadomy umysł jest jedynie iluzją, jakimś epifenomenalnym efektem elektrochemicznej aktywności mózgu. On sam argumentuje za tezą przeciwną: umysł żyje swoim życiem i potrafi formować oraz kontrolować procesy zachodzące w fizycznym mózgu. Proponowana przez niego niematerialistyczna interpretacja osiągnięć neuronauk ma zarazem pokazać ograniczenia teorii redukcjonistyczno-materialistycznych i eliminatywistycznych.

Schwartz omawia własne badania nad osobami z zaburzeniami obsesyjno-kompulsywnymi. Rozpoznają one natrętne myśli (część obsesyjna), które przymuszają je do rytualnych form zachowania (część kompulsywna). Na przykład po kilku obmyciach rąk osoba taka wie dokładnie, że jej ręce są czyste, a mimo to czuje się przymuszona do ich kolejnego umycia. Różnica między widocznym stanem faktycznym (ręce są czyste) a irracjonalnym wątpieniem (może są one brudne) skłoniła Schwartza do zbadania filozoficznych i neuronaukowych podstaw tego typu zachowań. Skanowanie określonych obszarów mózgu badanych osób wykazało charakterystyczne wzorce ich aktywności.

Schwartz zaproponował owym osobom poddanie się opracowanej przez niego tzw. 4R-terapii ([1] przemianowanie - relabelling, [2] ponowne przypisanie reattributing, [3] ponowne skupienie - refocusing, [4] ponowne ocenienie - revaluing). W przypadku wspomnianych osób terapia miała na celu doprowadzić do uznania przez nie, że ich ręce są czyste [1], przymus mycia rąk miał zostać postrzegany jako nieodnoszący się do rzeczywistości, a obawa, że ręce są brudne, miała zostać przypisana dysfunkcjom mózgu [2], skoncentrowana na myciu rąk uwaga osoby winna zostać skupiona na innym celu [3], co w konsekwencji 
powinno doprowadzić do zrozumienia przez osobę poddaną terapii absurdalności jej przymusowych zachowań [4]. Dodatkowe, piąte „R odnosi się do zmian zachodzących $\mathrm{w}$ formach aktywności mózgu (realignment).

Schwartz zauważył, że:

[i] osoby poddane terapii $4 \mathrm{R} \mathrm{w}$ istotny sposób uwolniły się od obsesywno-kompulsyjnych symptomów;

[ii] neuroobrazowanie ich mózgu ukazało korzystne przeformatowanie wzorców aktywności mózgowej. Zaszło to bez jakiegoś wyraźnego oddziaływania na mózg, czy to zewnętrznego (np. za pomocą magnetycznej stymulacji przezczaszkowej) czy to wewnętrznego (np. za pomocą medykamentów).

Osoby te odgórnie przeorganizowały funkcjonowanie swojego mózgu poprzez zmianę własnych myśli i zachowań. Istotnym odkryciem nie jest, że modyfikacja myślenia i form zachowania zmieniły w miarę stabilnie aktywność mózgu, lecz to, iż takie modyfikacje wynikły z „uważnej świadomości [...], która wywarła wpływ na ich mózg"28. Chodzi o świadome i sensowne myśli lub działania, w których osoba przyjmuje stanowisko niezaangażowanego obserwatora, natomiast zadaniem terapeuty jest zwrócenie jej uwagi na aspekty aktualnego doświadczenia, których być może sama by nie zauważyła.

2. Terapie pacjentów po udarze mózgu.

Udar oznacza masywną deformację sprawności mózgu w przekazywaniu informacji neuronalnej, objawiającą się zewnętrznymi konsekwencjami. Udar uszkadza zazwyczaj nie tylko system motoryczny osoby, lecz także jej system poznawczy i emocjonalny.

Powołując się na aktualne opracowania na temat udaru, Sjoerd de Vries stwierdza, że wyobrażanie sobie przez osobę po udarze mózgu jej własnych ruchów i obserwowanie ruchów innych osób okazuje się być skutecznym narzędziem, które można wykorzystać podczas rehabilitacji prowadzącej do poprawy lub nawet odzyskania sprawności motorycznej.

Obejmująca obrazy i wspomnienia wyobraźnia jest istotnym elementem naszej psychiki. Wyobraźnia motoryczna jest mentalnym wykonywaniem ruchu bez ruchu zewnętrznego lub bez aktywacji mięśni obwodowych. Wykazano, że wyobraźnia motoryczna prowadzi do aktywacji tych samych obszarów mózgu, co rzeczywiste ruchy. Obszary mózgu normalnie zaangażowane w planowanie ruchu i jego wykonanie są także aktywne w czasie wyobrażania sobie ruchu.

W wielu terapiach osób po udarze mózgu łączy się ruchowe ćwiczenia fizyczne z ruchami mentalnymi. Zachęca się pacjentów do słuchania nagranych objaśnień instruujących jak mają oni wyobrażać sobie ruchy swoich

28 J.M. Schwartz, S. Begley, The Mind and the Brain: Neuroplasticity and the Power of Mental Force, New York 2002, s. 335. 
dotkniętych skutkami udaru mózgu kończyn. Badania mierzące aktywność elektromiograficzną potencjałów motorycznych w korze motorycznej i przepływ krwi, pokazały, że w odpowiednich ścieżkach neuromotorycznych, ujawniających się podczas wyobrażania sobie ruchu, rośnie aktywność metaboliczna neuronów, przypominającą taką, z którą mamy do czynienia wówczas, kiedy ruch faktycznie jest wykonywany ${ }^{29}$.

Mentalna praktyka wyobrażania prowadzi tym samym do neuroplastycznych zmian w uszkodzonej, motorycznej korze mózgu, co z kolei pomaga osobie w odzyskaniu sprawności ruchowej.

Diana Carvalho i jej współpracownicy zaznaczają, że różne podejścia w rehabilitacji postudarowej świadczą o zdolności mózgu do znaczącej poprawy swojego funkcjonowania ${ }^{30}$. Jednym z przykładów jest zastosowanie przy porażeniu połowicznym tzw. terapii lustrzanej, umożliwiającej motoryczne symulowanie, a zarazem stymulowanie ruchów uszkodzonej kończyny i jej neurogicznych korelatów. Wykorzystując lustro, osoba przekazuje wizualne bodźce do uszkodzonej części mózgu dzięki obserwacji w lustrze ruchów niedotkniętej paraliżem części ciała ${ }^{31}$. W ten sposób, dzięki „lustrzanemu trikowi”, osoba oszukuje swój mózg, „przekonując go”, że jej osłabiona kończyna funkcjonuje normalnie, co w konsekwencji - dzięki neuroplastyczności mózgu - prowadzi do jego przeformatowania, a w rezultacie do powrotu do zdrowia.

\section{Podsumowanie i wnioski}

Strawson przyjmuje stanowisko Arystotelesa, że to, co pojedyncze (substancja z arystotelesowskich Kategorii), nie może w jakiejś wypowiedzi wystąpić na miejscu predykatu. Arystoteles nie posługuje się wprawdzie pojęciem osoby, zajmuje się jednak pytaniem, czy człowiek posiada duszę oddzieloną od ciała, (Platon), czy też pytaniem o psychoficzną jedność duszy i ciała, którą rozpatruje w ramach swojego hylemorficznego rozróżnienia na formę i materię.

Teorie eliminatywistyczne powstały na gruncie sceptycyzmu wobec metafizyki. Co jednak jest bardziej metafizyczne: proste założenie o istnieniu zjawisk duchowych, połączone z wymogiem ich wyjaśnienia, czy zagadkowe metafory

29 Por. S. de Vries, T. Mulder, Motor Imagery and Stroke Rehabilitation: A Critical Discussion, "Journal of Rehabilitation Medicine" 2007, t. 39, nr 1, s. 5-13.

30 Por. D. Carvalho, S. Teixeira, M. Lucas in., The Mirror Neuron System in Post-stroke Rehabilitation, "International Archives of Medicine" 2013, t. 41, nr 6, doi: 10.1186/17557682-6-41, https://www.ncbi.nlm.nih.gov/pubmed/24134862.

31 Por. M. Ietswaart, M. Johnston, Ch. Dijkerman i in., Mental Practice with Motor Imagery in Stroke Recovery: Randomized Controlled Trial of Efficacy, "Brain" 2011, t. 134, nr 5, s. 1373-1386. doi: 10.1093/brain/awr077, https://www.ncbi.nlm.nih.gov/pmc/articles/ PMC3097892/. 
i historyjki Dennetta, których nie może się on pozbyć i które potrzebują wyjaśnienia.

Wszystko, czego dokonałem, to zastąpienie jednej rodziny metafor i obrazów poprzez drugą; teatr, świadka, centralnego dawcę znaczenia i fantazję zamieniłem na software, wielokrotne szkice i miejsce pobytu homunkulusów. Jest to tylko wojna metafor - powiecie - ale metafory nie są „tylko” metaforami, metafory są narzędziami myślenia ${ }^{32}$.

Moja krytyka eliminatywizmu ma pokazać, czy strategia Dennetta odpowiada założonym przez niego celom: czy próbując wyeliminować to, co duchowe, przypadkiem coraz głębiej sam nie wikła się w myślenie quasi-metafizyczne, mimo że ciągle podkreśla, iż używa jedynie metaforycznych wyrażeń. Eliminatywista próbuje najpierw zredukować to, co duchowe, do tego, co neurologiczne, jeśli jednak taka redukcja się nie powiedzie (np. ze względu na pierwszoosobowy, subiektywny charakter doznań), wówczas dąży on do wyeliminowania tego, co duchowe. Mamy tutaj do czynienia z swego rodzaju błąd petitio principi: argumentując, zakłada się to, co chce się uzyskać jako wynik argumentowania. Bez owego nieuzasadnionego założenia, że coś duchowego nie istnieje, a istnieje jedynie to, co fizyczne, zbudowanej na tym założeniu argumentacji brak podstaw.

Można za Janem Pawłem II zapytać: czy kartezjańskie oddzielenie zjawisk duchowych od fizycznych nie prowadzi do niedopuszczalnej mistyfikacji tego, co duchowe? Czy Dennetta wskazanie na bezpodstawność zjawisk duchowych (wyrażanie tego, co duchowe, jedynie w kategoriach metafory stanów fizycznych) wystarczy uzasadnić tym, że używanie takich metafor niesie ze sobą doraźne korzyści?

Z proponowanymi, emergentnymi ujęciami osoby łączy się twierdzenie, że w systemach posiadających emergentne cechy występuje przyczynowość skierowana ku dołowi. Przypisując cechom mentalnym przyczynową rolę skierowaną ku dołowi, emergentyści muszą zrezygnować z tezy o przyczynowo-sprawczej zamkniętości obszaru fizycznego.

Rezygnując z możliwości wprowadzenia przyczynowości skierowanej ku dołowi, stoimy przed problemem właściwego ujęcia tego, co mentalne. Jedyną alternatywą wydaje się być wtedy epifenomenalizm. Wyjściem z powyższego impasu jest dopuszczenie - wzorem Arystotelesa - różnych rodzajów przyczynowości, przy czym przyczynowość skierowaną ku dołowi można rozumieć analogicznie do arystotelesowskiej przyczyny formalnej33.

32 D.C. Dennett, Consciousness Explained, s. 455.

33 Zagadnienia te omawiam bliżej w: J. Bremer, Przyczynowość skierowana ku dołowi $i$ jej rozumienie w biologii, „Poznańskie Studia z Filozofii Nauki” 2015, t. 24, nr 1, s. 93-115. 
Osoba może być rozumiana jako jednostka emergentna, odgrywająca rolę w jednoczeniu własności mentalnych skorelowanych z własnościami mózgu. Teoria silnej emergencji, jako teoria heurystyczna, posiada ogólną moc przewidującą i wyjaśniającą zasady rządzące ludzkim myśleniem i zachowaniem. Odwołując się do Jana Pawła II i rozwijanej przez niego arystotelesowsko-tomistycznej koncepcji osoby, możemy powiedzieć, że teoria silnej emergencji-przy odpowiednich modyfikacjach pojęciowych - spełnia podobną rolę wyjaśniającą ludzkie myślenie i zachowanie jak hylemorficzna teoria duszy u Arystotelesa. Relacja między osobą a jej mózgiem może być widziana jako adekwatne wyjaśnienie powiązania obserwowanego między potocznym (niemetaforycznym, nieiluzorycznym) rozumieniem osoby a mózgiem osoby, będącym przedmiotem badań neuronaukowych.

Słowa kluczowe: dualizm kartezjański, redukcjonistyczno-eliminatywistyczne teorie osoby, metafizyczne teorie osoby, emergencyjno-neuronaukowe teorie osoby, neuroplastyczność mózgu, neuronauki.

\section{Bibliografia:}

1. Bremer J., Neuronaukowy i potoczny obraz osoby w kognitywistyce, Kraków 2017.

2. Bremer J., Osoba - fikcja czy rzeczywistość?, Kraków 2008.

3. Bremer J., Przyczynowość skierowana ku dołowi i jej rozumienie w biologii, „Poznańskie Studia z Filozofii Nauki” 2015, t. 24, nr 1, s. 93-115.

4. Bremer J., Wprowadzenie do filozofii umystu, Kraków 2010.

5. Carvalho D., Teixeira S., Lucas M. i in., The Mirror Neuron System in Post-stroke Rehabilitation, "International Archives of Medicine" 2013, t. 41, nr 6, 2013, doi: 10.1186/1755-7682-6-41, https://www.ncbi.nlm.nih.gov/pubmed/24134862.

6. Crick F., Visual Perception: Rivalry and Consciousness, "Nature" 1996, nr 379, s. 485-486.

7. Dennett D. C., Consciousness Explained, Boston (MA) 1991.

8. Dennett D. C., Kinsbourne M., Time and the Observer, "Behavioral and Brain Sciences" 1982, t. 15, nr 2, s. 183-247.

9. De Vries S., Mulder T., Motor Imagery and Stroke Rehabilitation: A Critical Discussion, "Journal of Rehabilitation Medicine" 2007, t. 39, nr 1, s. 5-13.

10. Ietswaart M., Johnston M., Dijkerman C. i in., Mental Practice with Motor Imagery in Stroke Recovery: Randomized Controlled Trial of Efficacy, "Brain" 2011, t. 134, nr 5, s. 1373-1386.

11. Jan Paweł II, Adhortacja apostolska Reconciliatio et paenitentia, Vaticano 1984.

12. Jan Paweł II, Encyklika Fides et ratio, Poznań 1998.

13. Jan Paweł II, Pamięć $i$ tożsamość, Kraków 2005.

14. Jan Paweł II, Przekroczyć próg nadziei, Lublin 1994.

15. Kartezjusz, Rozprawa o metodzie, tłum. T. Boy-Żeleński, Warszawa 1934.

16. Martins A. M. (red.), Cause, Knowledge and Responsibility, Wien 2015. 
17. Schwartz J. M., Begley S., The Mind and the Brain: Neuroplasticity and the Power of Mental Force, New York 2002.

18. Sperry R. W., Discussion, [w:] The Central Nervous System and Behavior, M. A. B. Brazier (red.), Princeton (NJ) 1959, s. 416-422.

19. Sperry R. W., Mind, Brain, and Humanist Values, [w:] New Views of the Nature of Man, J. R. Platt (red.), Chicago 1965, ss. 71-92.

20. Strawson P. F., Indywidua. Próba metafizyki opisowej, tłum. B. Chwedeńczuk, Warszawa 1980.

21. Trevarthen C., Editor's Preface, [w:] Brain Circuits and Functions of the Mind, C. Trevarthen (red.), Cambridge 1990, s. xxvi-xxxvii.

22. Wojtyła K., Osoba i czyn, Kraków 1969. 